\title{
An Overview of Agrochemicals and Their Effects on Environment in Nepal
}

\author{
Govinda Bhandari* \\ Progressive Sustainable Developers Nepal (PSD-Nepal), Kathmandu, Nepal \\ *Corresponding author: govindabhandari84@yahoo.com
}

Received March 05, 2014; Revised March 24, 2014; Accepted March 27, 2014

\begin{abstract}
Agrochemicals are the result of modern technology that depends on inorganic fertilizers and pesticides. Over use of these chemicals have severe effects on environment that may lead to an immediate and long term effects. Investigating farmers' awareness of agrochemicals residues and their behaviors regarding application is important in order to reduce human factors that negatively affect agricultural safety. This study focuses on a summary of both national and international studies regarding the effects of pesticide and chemical fertilizer residues on nature, as well as farmers' awareness of these effects. This research incorporates the actual performance of farmers of Rupandehi district on the issue of agrochemicals.
\end{abstract}

Keywords: agrochemicals, farmers' awareness, Rupandehi, Nepal

Cite This Article: Govinda Bhandari, "An Overview of Agrochemicals and Their Effects on Environment in Nepal.” Applied Ecology and Environmental Sciences, vol. 2, no. 2 (2014): 66-73. doi: 10.12691/aees-2-2-5.

\section{Introduction}

Agrochemicals (pesticides and fertilizers) are looked upon as a vehicle for improved crop production technology though it is a costly input. Balance use, optimum doses, correct method and right time of application of agrochemicals ensures increased crop production. The requirement of fertilizers and pesticides for crops differ according to soil and meteorology. The available soil analysis data indicated that the soil in Nepal is generally low to medium in total nitrogen content. Under such conditions supply of nitrogen (N) through external sources leads to increase in crop yield [48].

Pesticides include chemically synthesized compounds, devices or organisms that are routinely utilized in agriculture to manage, destroy, attack or repel pests, pathogens and parasites. Pesticides include both organic and inorganic moieties and may be classified into different groups based on their chemical composition. These pesticides include organochlorines, organophosphates, carbamates, formamidines, thiocyanates, organotins, denitrophenols, synthetic pyrethroids and antibiotics [9]. The fate, on application, of pesticides in the soil and the transport processes involved depend on the cumulative effects of the pesticide's characteristics (e.g., adsorptivity, solubility, volatility and degradation rate), the soil's charateristics (e.g., texture and organic matter), the application methods used (e.g., aerial or ground) and the site conditions (e.g., topography, weather and irrigation) [36].

Various fungicides such as Dithane M-45 (mancozeb), Dithane Z-78 (zineb), Fytolan or Blitox-50 (copper oxychloride) and Bavistin were evaluated as foliar sprays for the control of various foliar and cob rot diseases. Most of the fungicides with higher number of sprays significantly reduced the diseases and increased the grain yield. However, spraying fungicides for the control of maize diseases is not advisable in Nepal [48]. A number of fungicides were evaluated against head smut of maize. As a result seed treatment with Sumi 8 (diniconazole), Tilt (propiconazole), Raxil (tebuconazole) or Bayleton (triademefon) at the rate of $2 \mathrm{~g}$ or $\mathrm{ml} / \mathrm{kg}$ seed has been found most effective for the control of the diseases [6,43]. Chemicals as Hinosan, CGA 49104, Kasugamycin, Beam were found to be effective for the control of rice blast [16,44,58,61].

Certain pesticides, which are more resistant to degradation by abiotic (physical, chemical and other factors) and biotic (living organisms i.e. the micro, meso and macro organisms of the soil food web) agencies, leach into the lower strata of the soil, are absorbed by plant roots, accumulate in the food chain and are ultimately biomagnified in the food web. There have been several reports on the accumulation of pesticide residues in plant [5,62] and animal tissues [29,47,55]. The applied pesticide can be transported from the sprayed area to nontarget areas away from the crop, which thus affects not only pest species, but potentially non-target endangered species also [38].

Pesticide use in Nepal started in the early 1950s with DDT for malaria eradication. This was subsequently followed by other organochlorines (such as BHC, dieldrin, chlordane), organophosphates (like, ethyl parathion, methyl parathion, malathion, and oxydemeton methyl), carbamates and finally synthetic pyrethroids. Some years before use of Chlordane, DDT, Dieldrin, Endrin, Aldrin, Heptachlor, Toxafen, Mirex, BHC, Lindane, Phosphamidon, Orano mercury fungicides, Methyl parathion and Monocrotophos are banned in Nepal. A steadily increasing trend in pesticide use has been 
observed as shown in Figure 2. A total of 178 tons of pesticides were used in 2003, of which insecticides (58\%) and fungicides (31\%) made up the bulk consumed. The number of households using pesticides varies considerably across the country, with the Terai (plains) region having the highest users (25.04\% of land holdings) and the Mountains region having the least at about $7.14 \%$ of land holdings [15]. The Mid-hills region has an average of $8.38 \%$ of land holdings using pesticides; however, certain pocket-areas in Mid-hills near urban markets, have considerably higher pesticide use holdings. Generally, pesticide usage in Nepal is against pests such as brown plant hopper, fruit flies and diseases like late blight of potato and tomato [4].

While the amount of pesticides used in Nepal is regarded as insignificant (142 gm/ha; cited in [19] compared to the other countries, such as $500 \mathrm{gm} / \mathrm{ha}$ in India, $6.6 \mathrm{~kg} / \mathrm{ha}$ in Korea, and $12 \mathrm{~kg} / \mathrm{ha}$ in Japan [28]; what makes it critical is the fragile ecological balance of the Himalayan Mid-hills, lack of adequate knowledge on proper use, lack of awareness among users of health and environmental impacts, lack of extension support to ensure safety, and inadequate regulation by the government [19]. In Nepal, the adverse effects of pesticide use on human health have not reached alarming proportions [4]. The application of chemical fertilizers alone is no longer sustainable from soil health as well as economic point of view. Both maize and millet yield are responsive to the increasing amount of nitrogen and compost when applied together in maintaining and improving the productivity [48]. The common chemicals used in Nepal are tabulated below:

Table 1. Common chemicals used in Nepal

\begin{tabular}{|c|c|c|}
\hline Ammonium Molybdate $\left[\left(\mathrm{NH}_{4}\right)_{6} \mathrm{M}_{07} \mathrm{O}_{2} 4 \mathrm{H}_{2} \mathrm{O}\right]$ & Borax $\left(\mathrm{NA}_{2} \mathrm{~B}_{4} \mathrm{O}_{7} .10 \mathrm{H}_{2} \mathrm{O}\right.$ for soil application) & Calcium Ammonium Nitrate (25-0-0) \\
\hline Ammonium Phosphate Sulphate (20-20-0) & Borax Decahydrate $\left(\mathrm{Na}_{2} \mathrm{~B}_{4} \mathrm{O}_{\left.7.10 \mathrm{H}_{2} \mathrm{O}\right)}\right.$ & Calcium Ammonium Nitrate (26-0-0) \\
\hline $\begin{array}{l}\text { Ammonium Phosphate Sulphate Nitrate (20- } \\
\text { 20-0) }\end{array}$ & Chelated Iron as Fe-EDTA & Chelated Zinc as Zn-EDTA \\
\hline Ammonium Sulphate (21-0-0) & Copper Sulphate $\left(\mathrm{CuSO}_{4} .5 \mathrm{H}_{2} \mathrm{O}\right)$ & Diammonium Phosphate (18-46-0) \\
\hline Ferrous Sulphate $\left(\mathrm{FeSO}_{4} \cdot 7 \mathrm{H}_{2} \mathrm{O}\right)$ & Granular Single Super Phosphate $\left(16 \% \mathrm{P}_{2} \mathrm{O}_{5}\right)$ & Granular Urea $(46 \% \mathrm{~N})$ \\
\hline Granulated NPK (20-20-10) & Manganese Sulphate, Muriate of Potash (0-0-60) & NPK (10-26-26) \\
\hline NPK (12-32-16) & Potassium Sulphate $(0-0-50)$ & Powdered Single Super Phosphate $\left(16 \% \mathrm{P}_{2} \mathrm{O}_{5}\right)$ \\
\hline $\begin{array}{l}\text { SOLUBOR } \\
\left(\mathrm{Na}_{2} \mathrm{~B}_{4} \mathrm{O}_{7} \cdot 5 \mathrm{H}_{2} \mathrm{O}+\mathrm{Na}_{2} \mathrm{~B}_{10} \mathrm{O}_{16} \cdot 10 \mathrm{H}_{2} \mathrm{O}\right) \\
\text { foliar spray }\end{array}$ & Triple Super Phosphate T.S.P $\left(16 \% \mathrm{P}_{2} \mathrm{O}_{5}\right)$ & Urea $(46-0-0)$ \\
\hline Urea Ammonium Phosphate (28-28-0) & Zinc Hepta-Hydrate $\left(\mathrm{ZNSO}_{4} .7 \mathrm{H}_{2} \mathrm{O}\right)$ & Zinc Sulphate Monohydrate $\left(\mathrm{ZnSO}_{4} \cdot \mathrm{H}_{2} \mathrm{O}\right)$ \\
\hline
\end{tabular}
Source: MoAD, 2013 [46]

The biomagnification of pesticides in plant and animal tissues (particularly in lipid bodies) makes their use hazardous to health and may lead to several ailments. Over the decades, there has been a considerable increase in pesticide use and a simultaneous increase in the problem of biomagnification has been encountered in soil [29], in plant and animal products such as cereals [5], fruits and vegetables [62], and in milk and milk products [41]. In addition, there is the emerging problem of the development of pesticide-resistant pests, which may resist even higher concentrations of pesticides. The negative effects of applied pesticides in higher organisms include direct impacts such as fish kills, reproductive failure in birds and acute illnesses in humans. Human exposure to or ingestion of pesticides usually occurs as a result of the misapplication or careless disposal of unused pesticides and pesticide containers. Moreover, as the top consumers, humans are exposed to high levels of pesticides on ingesting contaminated plant and animal products [38]. Although pesticides are important, their effects on nontarget organisms are of great concern because this poses a risk to the entire ecological system [39]. In general, the effects of pesticides on microorganisms will vary depending on the chemical dosage, the properties of the soil and various environmental factors [24]. Because the application or extensive use of pesticides has led to a rapid decline in the quality of the organic matter in soil it also affects the diversity of the microbial flora and fauna. Several soil microbial enzymes are hampered or affected by the application of pesticides to the soil [38]. Nitrogen mineralization processes, such as ammonification and nitrification, are also affected by the application of pesticides, with the former being inhibited less because it is carried out by a vast diversity of microflora. [50] have shown that the organochlorine pesticides Lindane and dieldrin were more toxic than the organophosphate pesticides pirimphos methyl and malathion to Nitrsomonas, Nitrobacter and Thiobacillus. The application of herbicides can affect Rhizobium-legume symbiosis in several ways because herbicides can: (1) affect the host plant directly; (2) negatively affect the growth and survival of the rhizobia, thus reducing the potential for nodule formation; (3) reduce the efficacy of the rhizobia in terms of the ability to nodulate or form an effective symbiosis [2]; and (4) reduce the nitrogen-fixing effectiveness of the symbiosis via enzymatic inhibition or interruption of biochemical pathways in the bacteroids [23]. In certain instances, the application of pesticides may not have drastic effects on rhizobial growth or reduce the number or activity of rhizobia, however, subsequent nodule formation by rhizobia may be reduced leading to a reduction in nodule size and total nitrogen fixation [2]. Soil fungi have a greater ability to resist the application of pesticides, but the application of fungicides drastically affects their population and hence a variety of mineralization/decomposition processes controlled by them. The application of fungicide decreases both the number and type of soil fungi [38].

Government of Nepal (GoN) is the signatory of Stockholm Convention, Basel Convention and Rotterdam Convention to minimize environmental pollution and to manage agrochemicals, including pesticides. The Joint Secretary responsible for environment division at the MoAD has been assigned as the Designated National Authority (DNA) of Rotterdam Convention to look after agrochemicals, pesticides and pesticide waste management in the country. GoN has accorded high priority to integrated pest management (IPM) to minimize 
pesticide risk [51]. The important roles of IPM are envisioned as to: 1 ) reduce reliance on pesticides and encourage use of other alternatives, 2) encourage use of low risk pesticides in cases of inevitable pesticide use, 3) conserve and use useful natural enemies and parasites to suppress crop pests, and 4) raise farmers knowledge about pests, agro-ecosystem and the surrounding environment. The IPM program started in 1997 with the support of FAO has now been implemented in 62 of 75 districts with intensive program in 17 districts. There are 131 IPM groups and 3667 farmer field schools in the country [57].

This study explores the use of agrochemicals and focuses Rupandehi district of Nepal to assess the information on the use of agro chemicals at a local level.

\section{Materials and Methods}

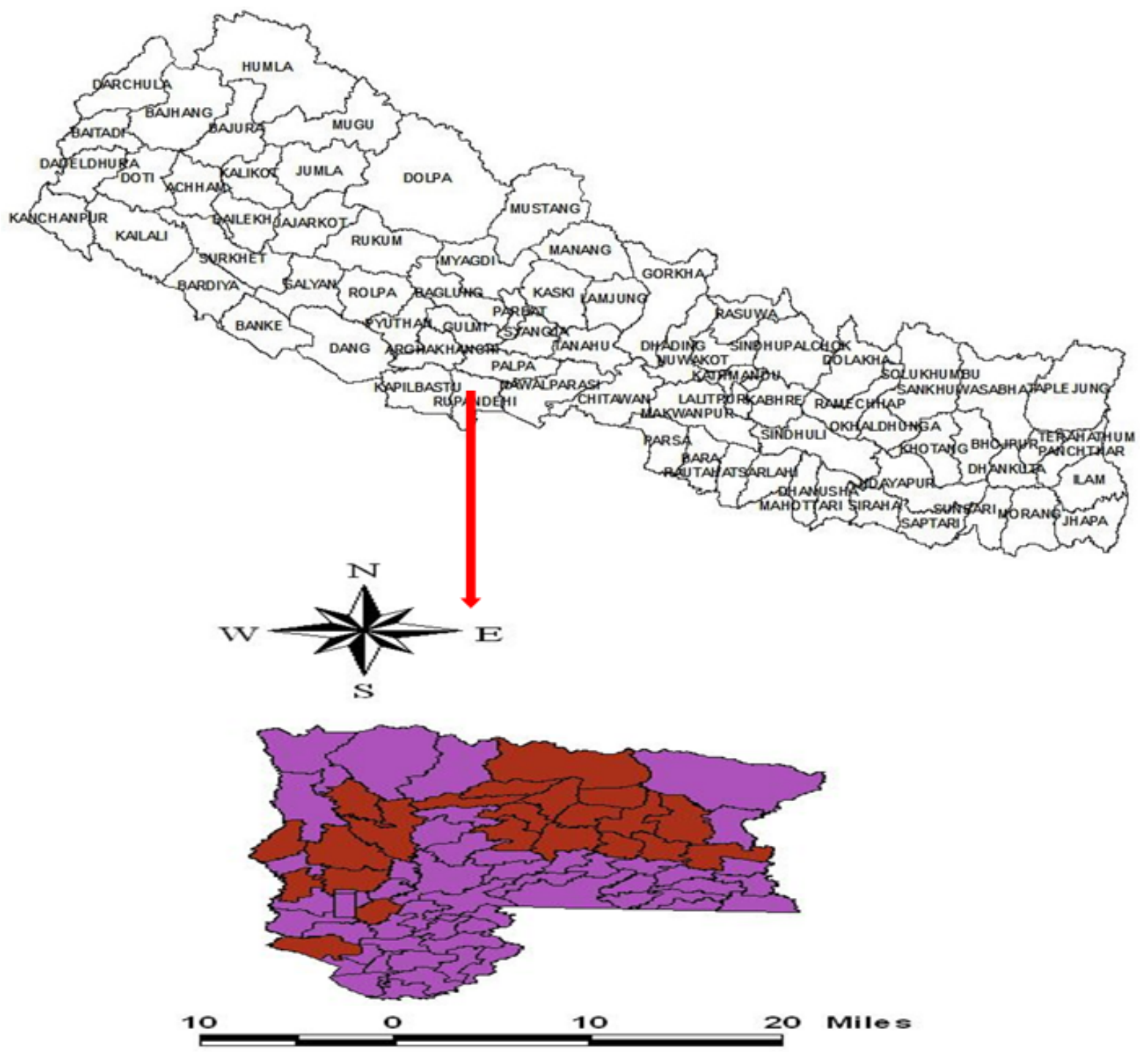

Figure 1. Map of Nepal and location of VDCs and a municipality

\subsection{Methodology}

The study was undertaken during the period between 16-23 October, 2008. Stratified random sampling was performed for the selection of 171 individuals from the 21 VDCs and 1 municipality. The interview was undertaken in sampled VDCs and a municipality. The individual who

\subsection{Study Area}

The study was conducted in Rupandehi district of Western Development Region (WDR) in Nepal as shown in Figure 1. Rupandehi district, a part of Lumbini zone, is one of the seventy-five districts of Nepal. The importance of this district lies in that Lumbini is the birth place of Lord Buddha and a major pilgrimage center for Buddhist. This district lies in the western Terai region of the WDR of Nepal. Its area is $1360 \mathrm{Km}^{2}$. It is situated between $27^{0}$ 20 ' $00^{\prime \prime}$ to $27^{0} 47^{\prime} 25^{\prime \prime}$ N latitude and $83^{\circ} 12^{\prime} 16^{\prime}$ to $83^{0}$ 38' 16" E longitude. The elevation ranges from 100-300 metres and the total population is about 7, 08,419 [14]. The maximum and minimum temperature recorded of this district is $47.7^{\circ} \mathrm{C}$ and $8.75^{\circ} \mathrm{C}$ respectively. The average annual rainfall is $1391 \mathrm{~mm}$. Tinahau, Rohidi, Danab, Pahala, Kanchan, Kothi, Danda and Koilimai are the important rivers of this district [13]. 
stipulated time few educated community leaders were trained and mobilized. The questions concerned: (i) if fertilizers and pesticides were used previously (ii) how often they were used and (iii) which pesticides were mostly applied and why (iv) the knowledge of pesticide toxicity symptoms (v) attitude towards the cost of the pesticides (vi) types of agrochemicals application method (vii) the fate of left over agrochemicals and storage (viii) the disposal of empty pesticide container (ix) the pesticide impact on environment and (x) how one can reduce the agrochemicals impact on human health and environment.

All the informants were actively involved and no one declined to finish the interview. Data analysis was performed by using ArcGIS, SPSS and MS Excel. The researcher revisits the households, if there were any mistake in the previously filled questionnaires.

\section{Results and Discussion}

\subsection{Negative Effects of Agrochemicals Residues}

Agricultural safety and the resulting environmental and health problems from pesticide application are increasingly attracting global attention [18,21,42]. However, a large input of pesticides leads to excessive residues that adversely affect the quality of agricultural goods [52]. Although the impacts of pesticides on agricultural products vary according to the type of pesticide used, all pesticide residues cause nutrient imbalance and reduction in the quality of agricultural products [10].

Pesticide residues affect human health. In fact, pesticide application has become a great threat to human health $[12,25,42,54]$. Studies have shown that long-term lowdose exposure to pesticides leads to the development of respiratory diseases such as asthma [30]. Such exposure also leads to reduced sperm quality and sperm count, causing sterility [60]. Pesticide poisoning is more significant in developing countries compared to developed countries. Pesticide residues affect environmental quality. Farmers serve as the main unit of agricultural production; their life and their daily production are closely related to the natural environment. Consequently, their irrational economic activities and unscientific ecological behaviour directly and inevitably worsens the ecological environment [8].

\subsection{Farmers' Awareness of Agrochemicals Residues}

Farmers serve as the main unit of pesticide application. Hence, their degree of awareness of pesticide residues inherently affects their methods of pesticide application. Whether they apply pesticides in a standardized method affects the generated amount of pesticide residues, thereby ultimately influencing the safe production of agricultural products [8].

171 household representatives were interviewed during the survey, making the response rate about $100 \%$ from the estimated households. Sociodemographic characteristics of respondents are shown in Table 2. The majority of the respondents had ample awareness about agricultural fertilizers and pesticides, in view of the fact that
Rupandehi is one of the major and well-known districts for the cultivation of agricultural crops in Nepal. As much as 170 (99.41\%) of the farmers had ample awareness regarding agrochemicals.

Table 2. Sociodemographic characteristics of the respondents with Gender, Religion, Age, Educational Status, Occupation and Awareness about agrochemicals

\begin{tabular}{|c|c|c|}
\hline Variables & $\mathrm{N}$ & Percentage \\
\hline \multicolumn{3}{|l|}{ Gender } \\
\hline Male & 129 & 75.43 \\
\hline Female & 42 & 24.56 \\
\hline \multicolumn{3}{|l|}{ Religion } \\
\hline Hindu & 156 & 91.22 \\
\hline Muslim & 14 & 8.18 \\
\hline Buddhist & 1 & 0.58 \\
\hline \multicolumn{3}{|c|}{ Age group of the respondents } \\
\hline 15-24 years & 7 & 4.09 \\
\hline 25-34 years & 12 & 7.01 \\
\hline 35-44 years & 14 & 8.18 \\
\hline $45-54$ years & 21 & 12.28 \\
\hline$\geq 55$ years & 26 & 15.20 \\
\hline NA & 91 & 53.21 \\
\hline \multicolumn{3}{|c|}{ Educational status } \\
\hline Illiterate & 14 & 8.18 \\
\hline Literate & 90 & 52.63 \\
\hline Sanskrit & 4 & 2.33 \\
\hline School & 34 & 19.88 \\
\hline HSS & 13 & 7.60 \\
\hline Bachelor & 10 & 5.84 \\
\hline Masters & 6 & 3.50 \\
\hline \multicolumn{3}{|l|}{ Occupation } \\
\hline Agriculture & 150 & 87.71 \\
\hline Officer & 1 & 0.58 \\
\hline Business & 10 & 5.84 \\
\hline Teaching & 10 & 5.84 \\
\hline \multicolumn{3}{|c|}{ Awareness about agrochemicals } \\
\hline Yes & 170 & 99.41 \\
\hline No & 1 & 0.58 \\
\hline
\end{tabular}

Nearly $42.69 \%$ and $33.33 \%$ of the farmers largely applied Urea + DAP + Potash and Animal Dung + Urea + DAP + Potash to get higher yield of crops (Table 3). Overall, $11.69 \%$ of the farmers indicated that they use compost manure to maintain fertility and increase yield (Table 3). A total of 150 (87.71\%) farmers $(N=171)$ were complaining that the costs of agrochemicals are extremely high. Similarly, 171 (100\%) respondents replied that agrochemicals are useful to some extent but causes environmental pollution and 10 (5.84\%) of the respondents considered that agrochemicals kill non-target organisms respectively. About, 123 (71.92\%) farmers stated that they have stockpiled the agrochemicals at separate place and locked. 21 (12.28\%) stated that they keep the agrochemicals outside the house i.e. on top of the house. However, a very few 17 (9.94\%) have indicated that they kept the agrochemicals along with other foodstuffs. Proper disposal of empty agrochemicals containers is one of the most important components in the safe use of pesticide management [40]. With reference to the disposal of leftover agrochemicals, a total of 12 (7.01\%) of the farmers indicated that they pour into bushes/river/stream, 60 (35.08\%) have indicated that they 
apply more than required, 4 (2.33\%) have indicated that they sold as in Table (Table 3).

Table 3. Perception of farmers towards agrochemicals and their sustainable use

\begin{tabular}{|l|l|l|}
\hline Variables & $\mathrm{N}$ & Percentage \\
\hline Cost of pesticides & 150 & 87.71 \\
\hline Extremely expensive & 21 & 12.28 \\
\hline Expensive & 0 & 0 \\
\hline Non expensive & \multicolumn{2}{|l|}{} \\
\hline Type of agrochemicals used & 4 & 2.33 \\
\hline Urea & 17 & 9.94 \\
\hline Animal dung & 57 & 33.33 \\
\hline Animal dung + Urea+ DAP + Potash & 73 & 42.69 \\
\hline Urea+ DAP + Potash & 20 & 11.69 \\
\hline Compost & \multicolumn{2}{|l|}{} \\
\hline Idea of bioaccumulation & 3 & 1.75 \\
\hline Yes & 168 & 98.24 \\
\hline No & \multicolumn{2}{|l|}{} \\
\hline Adverse
\end{tabular}

Adverse effects of agrochemicals*

\begin{tabular}{|l|l|l|}
\hline Environmental pollution & 171 & 100 \\
\hline Killing of non-target species & 10 & 5.84 \\
\hline Insecticide resistance & 5 & 2.92
\end{tabular}

Agrochemicals storage practice

\begin{tabular}{|l|l|l|}
\hline Hanging inside & 10 & 5.84 \\
\hline On top of the house & 21 & 12.28 \\
\hline Locked up in a safe place & 123 & 71.92 \\
\hline Along with food stuffs & 17 & 9.94 \\
\hline
\end{tabular}

Leftover agrochemicals solution

\begin{tabular}{|c|c|c|}
\hline Stored and used for another application & 95 & 55.55 \\
\hline Pour into bushes/river/stream & 12 & 7.01 \\
\hline Sell it to other farmers & 4 & 2.33 \\
\hline Apply even though it is not needed & 60 & 35.08 \\
\hline Disposed on the soil & 0 & 0 \\
\hline \multicolumn{3}{|c|}{ Disposal of empty agrochemicals containers } \\
\hline Use them for household purpose & 11 & 6.43 \\
\hline Buried & 25 & 14.61 \\
\hline Left in the farm/nearby farm itself & 50 & 29.23 \\
\hline Burnt & 45 & 26.31 \\
\hline NA & 40 & 23.39 \\
\hline
\end{tabular}

Whether you have received any training regarding the use of agrochemicals?

\begin{tabular}{|l|l|l}
\hline Yes & 4 & 2.33 \\
\hline No & 167 & 97.66 \\
\hline
\end{tabular}

Personal protective devices (PPDs)

\begin{tabular}{|l|l|l|}
\hline Yes & 21 & 12.28 \\
\hline No & 150 & 87.71 \\
\hline
\end{tabular}

Health impacts*

\begin{tabular}{|l|l|l|}
\hline Headache & 161 & 94.15 \\
\hline Fever & 60 & 35.08 \\
\hline Dizziness & 50 & 29.23 \\
\hline Abdominal pain & 29 & 16.95 \\
\hline Allergy & 30 & 17.54 \\
\hline Dermatitis and conjunctivitis & 80 & 46.78 \\
\hline
\end{tabular}

* Percentage do not add up to $100 \%$, because of multiple responses NA $=$ Not answered (Survey 2008)

\subsubsection{Awareness of the Danger of Excessive Agrochemicals Residues}

Although 90 (52.63\%) respondents were found literate, most respondents lack knowledge regarding the threats of excessive pesticide residues. Most farmers complained that pesticide labels are too complex and technical for them to understand. 17 (9.34\%) respondents of the total surveyed respondents had a certain amount of knowledge on the regulations regarding pesticide use, while 14 (8.18\%) of the respondents had no knowledge at all.

\subsubsection{Awareness of How Agrochemicals Residues Affect the Quality of Agricultural Products}

Farmers in Sichuan Province of China lack knowledge on pesticide toxicity and do not follow specific guidelines. Rather, they utilize a random method when applying different kinds of pesticides on different kinds of agricultural products. However, this study in Rupandehi district confirmed that 170 (99.41\%) individuals fully understand the basic method of agrochemicals application, 168 (98.24\%) still lack the concept of bioaccumulation and bio magnification, which lead to the accumulation of chemical residues in agricultural products in a greater amount.

\subsubsection{Awareness of Standardized Regulations in order to Reduce Agrochemicals Residues}

Farmers tend to apply pesticides excessively and irrationally because they do not understand the risks of pesticide residues, the guidelines on how much pesticide to use or the standardized regulations in pesticide application. This is the root of pesticide residue problems [66]. More frequent application of highly toxic pesticides leads to more pesticide residues persisting in agricultural products [32]. However, due to the lack of awareness of farmers, the misuse of pesticides has become a serious problem in agricultural production $[1,11,33]$. In case of Rupandehi, 60 (35.08\%) of the surveyed farmers tend to apply excess pesticide in order not to have any leftovers and $12(7.01 \%)$ pour the remaining chemicals in to the nearby river and bushes.

\subsection{Factors that Influence Farmers' Awareness of Agrochemicals Residues}

Many factors influence farmers' awareness of pesticides and pesticide residues. For example, [49] utilized a multi-variable model and concluded that the significant factors that influence farmers' awareness of pesticides include race, awareness of agricultural damage and awareness of health problems caused by pesticides, as well as whether they or their relatives have experienced damages caused by pesticides.

\subsubsection{Geographical Factors}

Due to different plantation structures and habits in different regions, levels of pest diseases, pesticide production and sales, as well as economic levels, are all different. Hence, the levels of pesticide awareness among farmers also differ. [20,64] believed that, among others, differences in annual income and geographical location can partly explain why farmers apply pesticides excessively. The amount of pesticides, especially highly toxic pesticides, applied in developing countries are considerably higher than in developed countries $[53,56]$. In Nepal also the trend of using chemicals (esp. Urea and DAP) is increasing since 2010 as in Figure 2. 


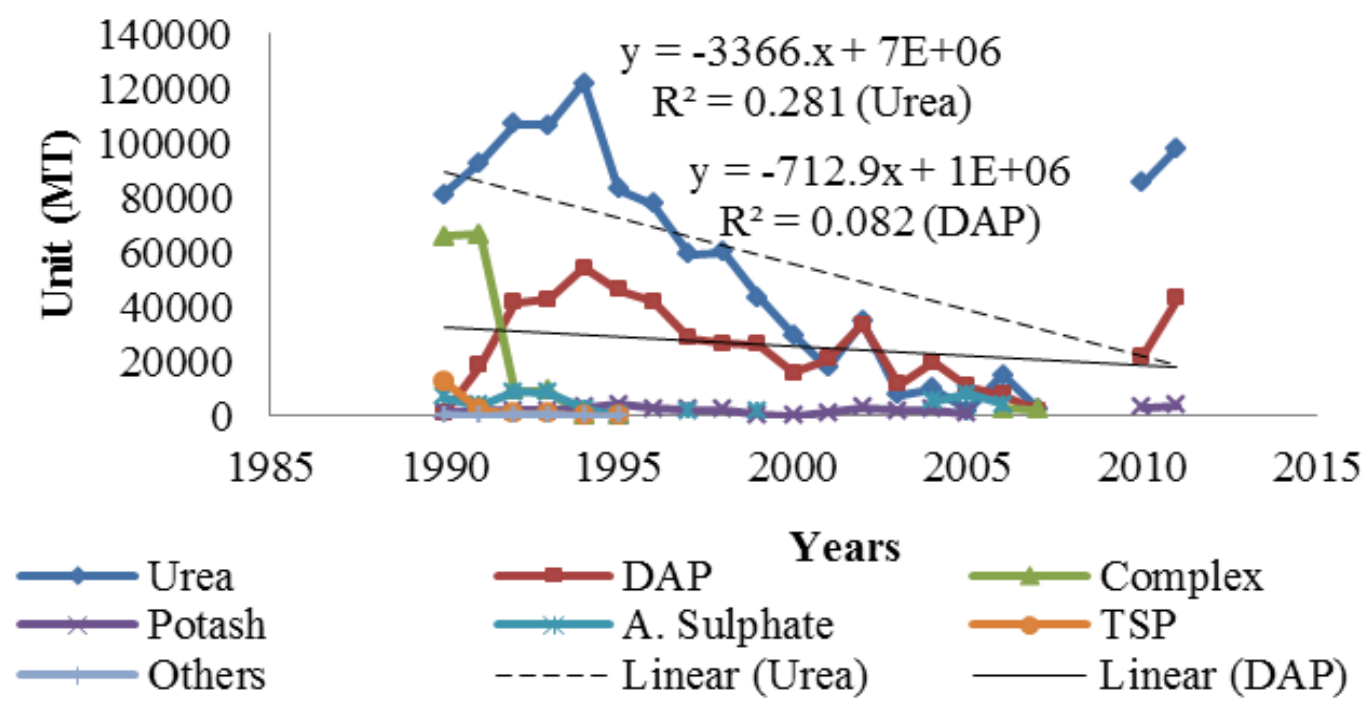

Figure 2. Trends of Chemicals used in Nepal

\subsubsection{Gender and Age}

Gender tends to influence awareness of the dangers of having pesticide residues [8]. In Nepal, women do not have a strong notion of the dangers caused by pesticides because they have relatively lower education levels [3]. In Rupandehi district, male respondents with age between 25-54, 29 (16.94\%) were found aware of food quality and safety standards.

\subsubsection{Education}

If a farmer is relatively less educated, his/her ability to absorb professional knowledge is weaker. Furthermore, his/her capability to recognize pest diseases is also weaker. Hence, the less-educated farmer tends to lack awareness of both pesticide residues and the importance of applying pesticide in standardized ways. Consequently, with less education, there is a higher chance that the farmer will apply prohibited pesticide excessively, leading to highly concentrated pesticide residues [34,63]. In Rupandehi, due to the lack of adequate knowledge regarding pesticides, 60 (35.08\%) farmers applied leftover chemicals even though it is not required. They rarely paid attention to the toxic side effects of chemicals on human health.

\subsubsection{Agricultural Use}

[65] found that farmers who plant rice to feed their own households tend to pay more attention to pesticide residue problems, while farmers who plant rice for commercial purposes pay more attention to the quantity of production. In Rupandehi, the respondents showed that individuals with larger plantation areas apply greater amounts of pesticides and sold their products in the market.

\subsubsection{Other Factors}

[22] found that the education and training provided by agricultural technology personnel affect farmers' awareness of pesticide residues. Rupandehi district where this study had been carried out lies near the border between Nepal and India. Farmers can have the availability of large quantity of agrochemicals promptly in comparison to other places. Also many private shops near Bhairahawa sell agrochemicals by which the farmers have easy access. This has encouraged the individuals to depend on chemicals instead of organic manure.

Remarkably, it was observed that the majority of the farmers indicated that appropriate use of agrochemicals could be helpful to reduce pesticide poisonings and environmental pollution. However, few respondents consider that applying the organic manure and bio chemicals and other chemicals could diminish the pesticides impact on environment and health (Table 3). Several studies have shown that by applying alternative and ecologically based methods, pesticide use can be decreased by at least 50\% without reducing the yield [31,35] and this might be one of the possibilities for controlling this increasing prevalence of pesticide poisonings and environmental hazard [37]. In addition, it could pave the way to minimize reliance of chemical pesticides The results of this study depict that respondents have the below satisfactory level of knowledge concerning pesticide label instructions, which is a key aspect for safe and sound practice of pesticide management.

In most cases, 45 (26.31\%) farmers burnt the empty agrochemicals containers, 11 (6.43\%) have indicated that they used for various household purposes (e.g., for food and water storage), 25 (14.61\%) indicated that they buried and $50(29.23 \%)$ indicated that they left the empty agrochemicals containers in the farm. Similar result has been reported; a study was carried out in Nigeria among the farmers indicated that they disposed of pesticide container by burying (25.0\%), burning (10.4\%), throwing into refuse heaps (2.1\%), and selling to buyers (25.0\%); however, the majority of them (35.4\%) washed their pesticide containers for other uses such as storing palm oil [59].

While spraying the pesticide, the use of personal protective devices (PPDs) could reduce its direct contact with the skin and inhalation of pesticides, thereby potentially reducing the acute and chronic health hazards to the sprayers [45]. Only $12.28 \%$ (21/171) of the farmers have been wearing appropriate PPDs such as safety shoes, respirator, gloves, goggles, and hat. Others have been applying the pesticides with their usual wear. Since it is a matter of great concern in terms of reducing pesticide poisoning, raising the awareness on the importance of proper usage of PPDs is extremely important in Nepal. 
Abdominal pain was the least common followed by allergy, 30 individuals (17.54\%); Dizziness, 50 (29.23\%) individuals; Fever, 60 (35.08\%); Dermatitis and Conjunctivitis, 80 (46.78) and Headache, 161 (94.15\%). Personal protective devices (PPDs) users were $4(2.33 \%)$ and 167 (97.66\%) did not use any devices.

The great majority of the farmers had not received any training/workshop about the harmful effect of agrochemicals and preventive measures to protect themselves and the environment, thus leading to dreadfully hazardous practices of pesticide management. Merely $2.33 \%$ of the farmers had received the training. The skills on agrochemicals among farmers can be increased by fostering the exchange of knowledge and information by almost all printed and electronic media in Nepal.

\section{Conclusion and Recommendation}

Agrochemicals are considered as a powerful weapon or magic bullets in the developing countries in order to enhance the agriculture productivity and considerably improve the major public health indices as well. However, it has been observed that agrochemicals are causing serious hazards. The present investigation results clearly suggest that the farmers had limited awareness about safe pesticide management and undesirable practice. Promotion of alternative pest control strategies such as application of bio-pesticides and integrated pesticide management (IPM) is apparently inevitable. Use of bio pesticides, bioremediation of pesticide-contaminated soils/land, utilization of plant-associated microbes, and effect of transgenic crop cultivation are some of the successful alternative strategies to pesticide use applied to date [38].

To annihilate the misunderstandings and undesirable practice regarding safe use of pesticide management, this investigation led to the following recommendations:

i. Government of Nepal should develop good mechanism for enforcing the regulations for the overall management and use of pesticides, adopting FAO guidelines with adequate educational and training interventions.

ii. Raising the awareness of the grass roots and designing ways of solving existing problems that resulted from improper utilization of agrochemicals. Research and development on the use of biopesticides and eco-friendly measures are highly recommended to minimize the use of hazardous pesticides.

iii. There should be an approach to pesticide management and close collaboration of health, agriculture, and environment sectors.

iv. Prevention and management of pesticide poisoning, and for enhanced surveillance, training is extremely important and must be carried out by the concerned authorities. For this a central authority for chemical safety needs to be formed to work effectively on chemical safety and risk management.

The impact of pesticides on the human immune system has also attracted attention from scholars [7,17,26,27]. Scholars agree that certain pesticides may affect the human endocrine and immune systems. They also agree that pesticides may promote the development of cancer.
Therefore, long-term environmental and health impacts of agrochemicals should be researched in depth in the future.

\section{Acknowledgement}

The author acknowledges the remarks and the suggestion on the manuscript and would like to thank anonymous reviewer(s). The author also takes this opportunity to thank the University Grants Commission (UGC), Nepal for the financial support and all the individuals who helped technically during the survey.

\section{References}

[1] Abhilash PC, Singh N. 2009. Pesticide use and application: An Indian scenario. Journal of Hazardous Materials, 165(1-3), 1-12.

[2] Anderson A, Baldock JA, Rogers SL, Bellotti W, Gill G. 2004. Influence of chlorsulfuron on rhizobial growth, nodule formation, and nitrogen fixation with chickpea. Aust J Agr Res. 55:10591070 .

[3] Atreya K. 2007. Pesticide use knowledge and practices: A gender differences in Nepal. Environmental Research, 104, 305-311.

[4] Atreya K. 2008. Probabilistic assessment of acute health symptoms related to pesticide use under intensified Nepalese agriculture, International Journal of Environmental Health Research, 18:3, 187-208.

[5] Babu GS, Farooq M, Ray RS, Joshi PC, Viswanathan PN, Hans RK. 2003. DDT and HCH residues in basmati rice (Oryza sativa) cultivated in Dehradun (India). Water Air Soil Pollut. 144:149-157.

[6] Batsa BK, Manandhar G. 1994. Suppression of maize head smut with seed treatment and influence of planting date on disease incidence. Paper presented at the Eighteenth Summer Crops Workshop held at ARS, Rampur from March 1 to 2, 1994.

[7] Beil D, Ring J, Vieluf D, Kinder H, Behrendt H, Paschke A, Steinhart H. 2001. Modulation of allergic reactions to apple by pesticide residues. Food and Agricultural Immunology, 13, 93-102.

[8] Bo Hou, Linhai Wu. 2010. Safety impact and farmer awareness of pesticide residues, Food and Agricultural Immunology, 21:3, 191200.

[9] Bohmont BL. 1990. The standard pesticide user's guide. Upper Saddle River (NJ): Prentice Hall.

[10] Bourn D, Prescott JA. 2002. Comparison of the nutritional value, sensory qualities, and food safety of orbanically and conventionally produced food. Critical Reviews in Food Safety and Nutrition, 42(1), 1-34.

[11] Brauw A, Huang J, Rozelle S. 2000. Responsiveness, flexibility and market liberalization in Chinese agriculture. American Journal of Agricultural Economics, 82, 1133-1139.

[12] Buczynska A, Szadkowska-Stanczyk I. 2005. Identification of health hazards to rural population living near pesticide dump sites in Poland. International Journal of Occupational Medicine and Environmental Health, 18, 331-339.

[13] Central Bureau of Statistics (CBS). 2007. District profile of Rupandehi. Central Bureau of Statistics. National Planning Commission Secretariat, Kapilbastu, Nepal, pp 104.

[14] Central Bureau of Statistics (CBS). 2006. Nepal in figures. Central Bureau of Statistics. National Planning Commission Secretariat, Kathmandu, Nepal, pp 12.

[15] Central Bureau of Statistics (CBS). 2003. National Sample Census of Agriculture, Nepal, 2001/02: highlights. Government of Nepal (Kathmandu): National Planning Commission and Central Bureau of Statistics.

[16] Chaudhary B. 1995. Efficacy of Beam 75 wp in controlling leaf blast disease at the seedling stage or rice. Paper presented at the $18^{\text {th }}$ National Summer Crops Workshop at National Maize Research Program, Rampur, Nepal.

[17] Christin MS, Ménard L, Gendron AD, Ruby S, Cyr D, Marcogliese DJ, Rollins- Smith L, Fournier M. 2004. Effects of agricultural pesticides on the immune system of Xenopus laevis and Rana pipiens. Aquatic Toxicology, 67, 33-43.

[18] Cooper J, Dobson H. 2007. The benefits of pesticides to mankind and the environment. Crop Protection, 26, 1337-1348. 
[19] Dahal L. 1995. A study on pesticide pollution in Nepal. Kathmandu (Nepal): National Conservation Strategy Implementation Project, IUCN/Nepal.

[20] Dasgupta S, Meisner C, Huq M. 2007. A pinch or a pint? Evidence of pesticide overuse in Bangladesh. Journal of Agricultural Economics, 1, 91-114.

[21] Dinham B, Malik S. 2003. Pesticides and human rights. International Journal of Occupational and Environmental Health, 9, 40-52.

[22] Dongmei Z. 2006. Development of bio-pesticide industry in China. Unpublished PhD thesis, Fujian University of Agriculture and Forestry, Fujian, China.

[23] Drew EA, Gupta VVSR, Roget DK. 2007. Herbicide use, productivity, and nitrogen fixation in field pea (Pisum sativum). Aus J Agr Res. 58:1024-1214.

[24] Ecobichon DJ. 1991. Toxic effects of pesticides. In: Amdur MO, Donl J, Klassen CD, editors. Casarett and Doull's toxicology. 4th edition. New York: Pergamon Press. p. 2-18.

[25] Elfvendahl S, Mihale M, Kishimba MA, Kylin H. 2004. Pesticide pollution remains severe after cleanup of a stockpile of obsolete pesticides at Vikuge, Tanzania. Ambio, 33, 503-508.

[26] Galloway T, Handy R. 2007. Immunotoxicity of organophosphorous pesticides. Ecotoxicology, 12(1-4), 345-363.

[27] Gu X, Tian S. 2005. Pesticide and cancer. World's Scientific Technology and Develoment, 27(2), 47-52.

[28] Gupta PK. 2004. Pesticide exposure - Indian scene. Toxicology. 198:83-90.

[29] Hans RK, Farooq M. 2000. Dissipation and accumulation kinetics of lindane in soil and earthworms. Pollut Res. 19:394-396.

[30] Hoppin JA, Umbach DM, London SJ, Alavanja MCR, Sandler DP. 2002. Chemical predictors of wheeze among farmer pesticide applicators in the agricultural health study. American Journal of Respiratory and Critical Care Medicine, 5, 683-689.

[31] Hruska AJ, Corriols M. 2002. The impact of training in integrated pest management among Nicaraguan maize farmers: increased net returns and reduced health risk. Int J Occup Environ Health. 8:191-200.

[32] Hu D, Chen Z, Sun Q. 2006. Implications of production model on farm household income and food safety - a case study of apple industry in Shandong Province. China's Rural Economy, 11, 1724.

[33] Huang J, Rozelle S, Pray C. 2002. Enhancing the crops to feed the poor. Nature, 418, 678-684.

[34] Huang Y, Liu L, Pei E. 2008. Vegetative pesticide residue and application behavior in Beijing. Chinese Journal of Food Hygiene, 20, 319-321.

[35] International Centre for Pesticide Safety (ICPS). 1999. The consequences of reducing the use of pesticides have now been clarified. Pesticide Saf News: 2(3):1-7.

[36] Jeong H, Forster L. 2003. Empirical investigation of agricultural externalities: effects of pesticide use and tillage system on surface water. Department of Agricultural, Environmental and Development Economics, The Ohio State University, Working Paper: AEDE-WP-0034-03. p. 31.

[37] Jors E. 2004. Acute Pesticide Poisonings Among Small-Scale Farmers in La Paz County, Bolivia [master's thesis]. Copenhagen: University of Copenhagen.

[38] Kalia A, Gosal SK. 2011. Effect of pesticide application on soil microorganisms, Archives of Agronomy and Soil Science, 57:6, 569-596.

[39] Kalia A, Gupta RP. 2004. Disruption of soil foodweb by pesticides. Ind J Ecol. 31(2):85-92.

[40] Kaliyaperumal Karunamoorthi MSc, MPhil, DPHM, PhD Mubarek Mohammed BSc \& Fantahun Wassie, M.Sc. 2012. Knowledge and Practices of Farmers With Reference to Pesticide Management: Implications on Human Health, Archives of Environmental \& Occupational Health, 67:2, 109-116.

[41] Kannan K, Tanabe S, Giesy JP, Tatsukawa R. 1997. Organochlorine pesticides and polychlorinated biphenyls in foodstuffs from Asian and oceanic countries. Rev Environ Contam Toxicol. 152: 1-55.

[42] Leyk S, Binder CR, Nuckols JR. 2009. Spatial modeling of personalized exposure dynamics: The case of pesticide use in small-scale agricultural production landscapes of the developing world. International Journal of Health Geographics, 8(17), 1-16.
[43] Manandhar G. 1992. Effect of fungicides to control head smut disease of maize. Paper presented at the Summer Crops Workshop held at ARS, Rampur from January 28-31, 1992.

[44] Manandhar HK, Thapa BJ, Amatya P. 1985. Efficacy of various fungicides on the control of Rice Blast disease. J. Inst. Agric. Anim. Sci. (Nepal) 6: 21-29.

[45] Mekonnen Y, Agonafir T. 2002. Effects of pesticide applications on respiratory health of Ethiopian farm workers. Int J Occup Environ Health.2002; 8: 35-40.

[46] Ministry of Agriculture Development (MoAD). 2013. Report on Chemical fertilizers. Ministry of Agriculture Development, Kathmandu, Nepal. pp. 1-8.

[47] Nakata H, Kawazoe M, Arizono K, Abe S, Kitano T, Shimada H, Li W, Ding X. 2002. Organochlorine pesticides and polychlorinated biphenyl residues in foodstuffs and human tissues from China: status of contamination, historical trend, and human dietary exposure. Arch Environ Contam Toxicol. 43(4):473-480.

[48] National Agricultural Research Council (NARC). 1997. 25 Years of Maize Research in Nepal (1972-1997). NARC, National Maize Research Program, Nepal. Pp. 1-44.

[49] Nicol A. 2003. Perceptions of pesticides among farmers and farm family members. Unpublished Ph.D. thesis, University of British Columbia, Vancouver, BC, Canada.

[50] Odokuma LO, Osuagwu C. 2004. Tolerance of chemolithotrophic bacteria to organochlorine, organophosphate and carbamate pesticides. J Agr Environ Eng Technol. 1(1):7-15.

[51] Plant Protection Directorate (PPD). 2008. Annual Progress Report, Plant Protection Directorate, Harihabhawan, Kathmandu, Nep al.

[52] Qi L, Fu Z, Shi Y. 2002. Pesticide application technology and food product safety. Journal of Agricultural Engineering, 6, 203206.

[53] Rahman S. 2003. Farm-level pesticide use in Bangladesh: Determinants and awareness. Agriculture. Ecosystems and Environment, 95, 241-252.

[54] Sivanesan SD, Krishnamurthi K, Wachasunder SD, Chakrabarti T. 2004. Genotoxicity of pesticide waste contaminated soil and its leachate. Biomedical and Environmental Sciences, 17, 257-265.

[55] Sofina LI, Kolycheva SS, Zaria NIU. 1993. Pesticide levels in food of pregnant women and newborn in rice growing areas of Kransnodar region. Vopr Pitan. 4: 53-54.

[56] Tariq MI, Hussain I, Afzal S. 2003. Policy measures for the management of water pollution in Pakistan. Pakistan Journal of Environmental Science, 3, 11-51.

[57] Thapa B, Manandhar HK, Shrestha SM, Pradhan SB. 2012. Use of Pesticides in Nepal and Impacts on Human health and Environment. Ministry of Agriculture Development (MoAD). Vol. 13. Pp. 71-74.

[58] Thapa BJ. 1975. Report on rice diseases. Pages 13-15 in: Summary of the Rice Improvement Workshop, NRIP, Nepal.

[59] Tijani AA. 2006. Pesticide use practices and safety issues: the case of cocoa farmers in Ondo State, Nigeria. J Hum Ecol. 2006; 19:183-190

[60] Tuc VP, Wangsuphachart V, Tasanapradit P, Fungladda W, Van Trong P, Nhung NT. 2007. Impacts of pesticide use on semen characteristics among rice farmers in Kienxuong District, Thaibinh Province, Vietnam. Southeast Asian Journal of Tropical Medicine and Public Health, 3, 569-575.

[61] Upadhyay BP. 1983. How to produce a healthy rice seed: a proposal. Paper presented at the National Seed Seminar, Kathmandu, Feb 16-20, 1983.

[62] Waliszewski SM, Carvajal O, Gomez-Arroyo S, Amador-Munoz O, Villalobos-Pietrini R, Hayward-Jones PM, Valencia-Quintana R. 2008. DDT and HCH isomer levels in soils, carrot root and carrot leaf samples. Bull Environ Contam Toxicol. 81:343-347.

[63] Xu Y. 2004. Survey of improper pesticide application in rice production. Jiangxi Agricultural Technology, 11, 27-28.

[64] Yang T. 2006. An empirical study of agricultural product safety. Unpublished Ph.D. thesis, Nanjing Agricultural University, Nanjing, China.

[65] Zhao J, Zhang Z. 2007. Influence factors of safe production of agricultural goods. Statistics Research, 90-92.

[66] Zhou J, Jin A. 2009. Safety of vegetables and the use of pesticides by farmers in China: Evidence from Zhejiang province. Food Control, 20, 1043-1048. 